\title{
Parameters, Interrelationships with Yield and use of Carbofuran to Control Stem Borers in Maize (Zea mays I.) at Makurdi in the Nigerian Southern Guinea Savanna
}

\section{Okweche S. I. ${ }^{* 1}$, Ogunwolu E. O. ${ }^{2}$, Adeyemo M. O. ${ }^{3}$}

\author{
${ }^{1}$ Department of Crop Science, University of Calabar, P. M. B. 1115, Calabar, Nigeria. \\ ${ }^{2}$ Department of Crop \& Environmental Protection, University of Agriculture, P. M. B. 2373, \\ Makurdi, Benue State, Nigeria. \\ ${ }^{3}$ Department of Crop Production, University of Agriculture, P. M. B. 2373, Makurdi, Benue State, \\ Nigeria.
}

\section{ARTICLE INFO}

Article No.: 170913845

DOI: 10.15580/GJAS.2013.10.170913845

Submitted: $17 / 09 / 2013$

Accepted: 22/10/2013

Published: 29/10/2013

*Corresponding Author

Okweche S. I.

E-mail: idokosi@yahoo.com

Phone: +237034967125

Keywords:

Maize, stem borer, damage, control, carbofuran

\section{ABSTRACT}

Early and late crops of flint, pop and sweet maize (Zea mays L.) were sown in field plots laid in randomized complete block design at the Teaching and Research Farm in 2004. Stem borer infestation and damage were assessed both in the plots treated with $1.5 \mathrm{~kg}$ carbofuran/ha and in those not treated for stem borer control. The maize types, as subplot treatments, and carbofuran application vs no application, as main plot treatments, were replicated four times. Borer damage was quantified as percentage dead-heart, bored stems, lodged stems, bored internodes, and as numbers of borer larvae/stem and borer cavities. The damage parameters were correlated with each other and with yield. Busseola fusca Fuller was the most abundant species; borer infestation was 5 times higher in the late than in the early crop and application of carbofuran resulted in 86.8 and $63.5 \%$ control, respectively. Yield loss due to borer damage to the early crop was $14.0 \%$; that for the late crop was 1.5-fold higher. In both crops, maize type exerted no significant effect $(P>0.05)$ on borer damage. Percentage bored internodes was positively and significantly ( $P$ $<0.01$ ) correlated with number of bored stems ( $r=0.95$, early crop; 0.88 , late crop), and lodged stems ( $r=0.82$, early crop; 0.83 , late crop). Similarly, bored and lodged stems were positively correlated $(r=0.75$ and 0.74 , respectively in the early and late crop; $\mathbf{P}<0.01)$. Dead-heart was positively correlated with each stem damage parameter; coefficients of correlation were higher for the early than the late crop. All damage parameters were negatively correlated with yield but a robust yield loss predictive model was not found. As such, use of carbofuran against maize stem borers would continue to be prophylactic at Makurdi. 


\subsection{INTRODUCTION}

In Nigeria, and indeed in most of Sub-Saharan Africa, maize [Zea mays L. (Poaceae)] derives socio-economic importance from its value as staple food item (contributing to household food security), animal feed, agro-industrial and trade item, thereby growing the economy and alleviating poverty (Effa et al., 2012; Farid et al., 2007; Tena and Beyene, 2011). Nigeria is Africa's largest producer of maize (IITA, 2013); production traverses diverse agro-ecological zones (from the rainforest to the Northern Guinea Savanna), and cropping systems prevalently small-scale, rain-fed and polycultural (Undie et al., 2012). The annually increasing rate of output (Fig. 1) is largely attributable to expansion of hectarage cultivated (Badmus and Ariyo, 2011). Yield-constraining factors include non-adoption or inefficient application of improved production technology, non-existent or low-level plant health management skill, low capital outlay and inefficient resource utilization (Anon., 2012; Badmus and Ariyo, 2011).

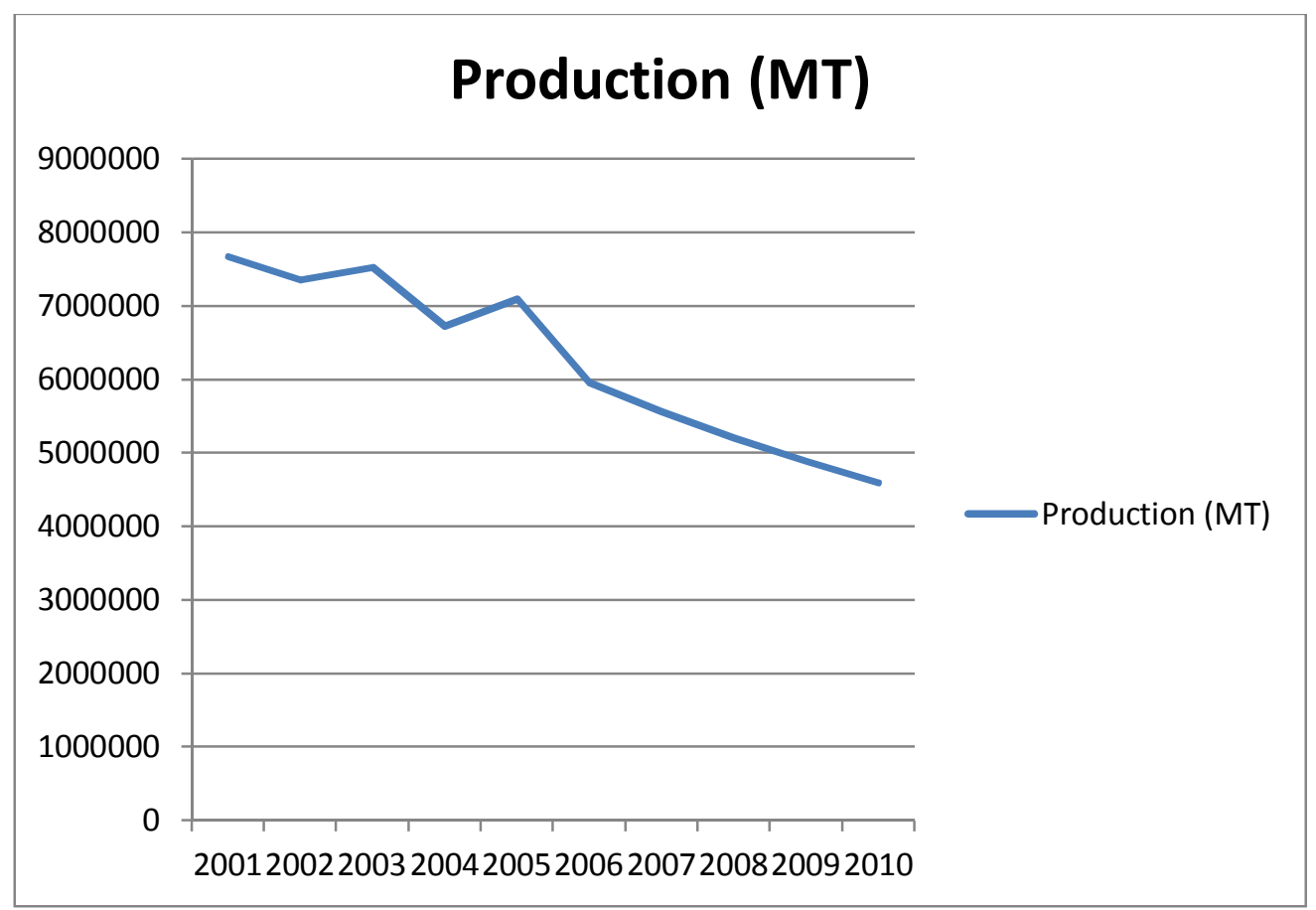

Fig. 1. Trend in production of maize in Nigeria - 2001 - 2010

Of the biotic constraints to high productivity, the noctuid and pyralid pests (Busseola fusca Fuller; Sesamia spp. Hampson, and Eldana saccharina Walker, Chilo partellus Swinhoe) are regular pests. Feeding injury occurs from the vegetative plant growth stages to maturity and is visible on the leaf (window pane), shoots (dead-heart, stand loss), stem (perforation, tunneling, lodging, and breakage), tassel, and ear (shank damage, tunneling, premature cessation of grain filling) (Bosque-Perez, 1995; Bosque-Perez and Mareck, 1991; Leyenaar and Hunter, 1977; Sharma and Gautam, 2010; van den Berg, 2009). The consequence on yield is variable (negligible to total crop loss) depending upon location, season, sowing date, borer species composition, level of abundance, varietal susceptibility, and plant-pest interaction as mediated by the climatic, edaphic and biotic environment (Ajala et al., 2010; Kekule et al., 1997; Okweche et al., 2010; Sosan and Daramola, 1999; Ukeh et al., 2007;).
The prevalence of $B$. fusca followed by $S$. calamistis on the early- and/or late-sown maize at Makurdi, Benue State, Calabar, Cross River State, and south-western Nigeria has been established (Balogun and Tanimola, 2001; Okweche et al. 2010; Okweche and Umoetok, 2012). These and other borer species on maize are effectively controlled by applying carbofuran as seed treatment, whorl leaf treatment, single or split dose soil treatment (Egwuatu and Ita, 1982; Ogunwolu, 1987).

Application of carbofuran for the control of maize stem borers has continued to be prophylactic on account of paucity of robust yield loss predictive models premised upon early borer damage parameters. Ajala and Saxena (1994) studied the interrelationship among parameters of damage caused by Chilo partellus and their contribution to yield loss in maize. A related study was carried out at Ile-Ife in south-western Nigeria (where the predominant borer species were $S$. calamistis, Eldana saccharina, and B. fusca) by Sosan and Daramola (1999). In this paper we 
report findings from a study on the interrelationships among stem borer infestation, damage and yield of earlyand late-sown maize at Makurdi in the Nigerian Southern Guinea Savanna.

\subsection{MATERIALS AND METHODS}

The experiment was laid in randomized complete block design with split-plot arrangement of treatments each of which was replicated four times at the Teaching and Research Farm of the University of Agriculture, Makrudi. Three genotypes of maize, namely, flint, pop, and sweet, sown in July (early crop) or August (late crop) constituted subplots in main plots that were either treated with $1.5 \mathrm{~kg}$ carbofuran/ha (Furadan $3 \mathrm{G}^{\circledR}$ ) or left untreated. The plots were $5 \mathrm{~m}$ long and $3.75 \mathrm{~m}$ wide with $0.75 \mathrm{~m}$ inter-space between rows and $1 \mathrm{~m}$ between replications. The intrarow spacing was $0.50 \mathrm{~m}$ and there were two plants per stand. Carbofuran was applied into furrow $4 \mathrm{~cm}$ from the plants first at 3 weeks after planting (WAP) and at 7 WAP.

At 6 WAP, the number of plants killed by stem borers (dead-heart) was counted and expressed as a proportion of the total number of plants within each plot. At harvest, stem lodging in each subplot was quantified and expressed as a percentage of the total number of stems. Thereafter, a random sample of 10 stems per subplot was taken to record number bored and proportion of internodes bored. Bored stems were split to recover borer larvae and measure tunnel length from which number of borer cavities was derived as a quotient using the length of the mature larva of $B$. fusca, the predominant borer species at the study site, as the divisor. Maize ears from each subplot were harvested, dried, threshed and weighed; a sample of 1000 grains was also weighed.

Combined borer damage and yield data for the early- and late-crop were subjected to analysis of variance after arcsin transformation of data in percentages. Correlation analysis was used to detect relationship between borer damage parameters and yield as well as to detect interrelationships between borer damage parameters.

\subsection{RESULTS}

In the untreated plots, borers recovered from bored stems of late-planted maize were 5 times more than the number on early-planted maize. Across both plantings, B. fusca was the most predominant species followed in descending order by $S$. calamistis, $E$. saccharina, Coniesta ignefusalis and C. partellus (Fig. 2 ).

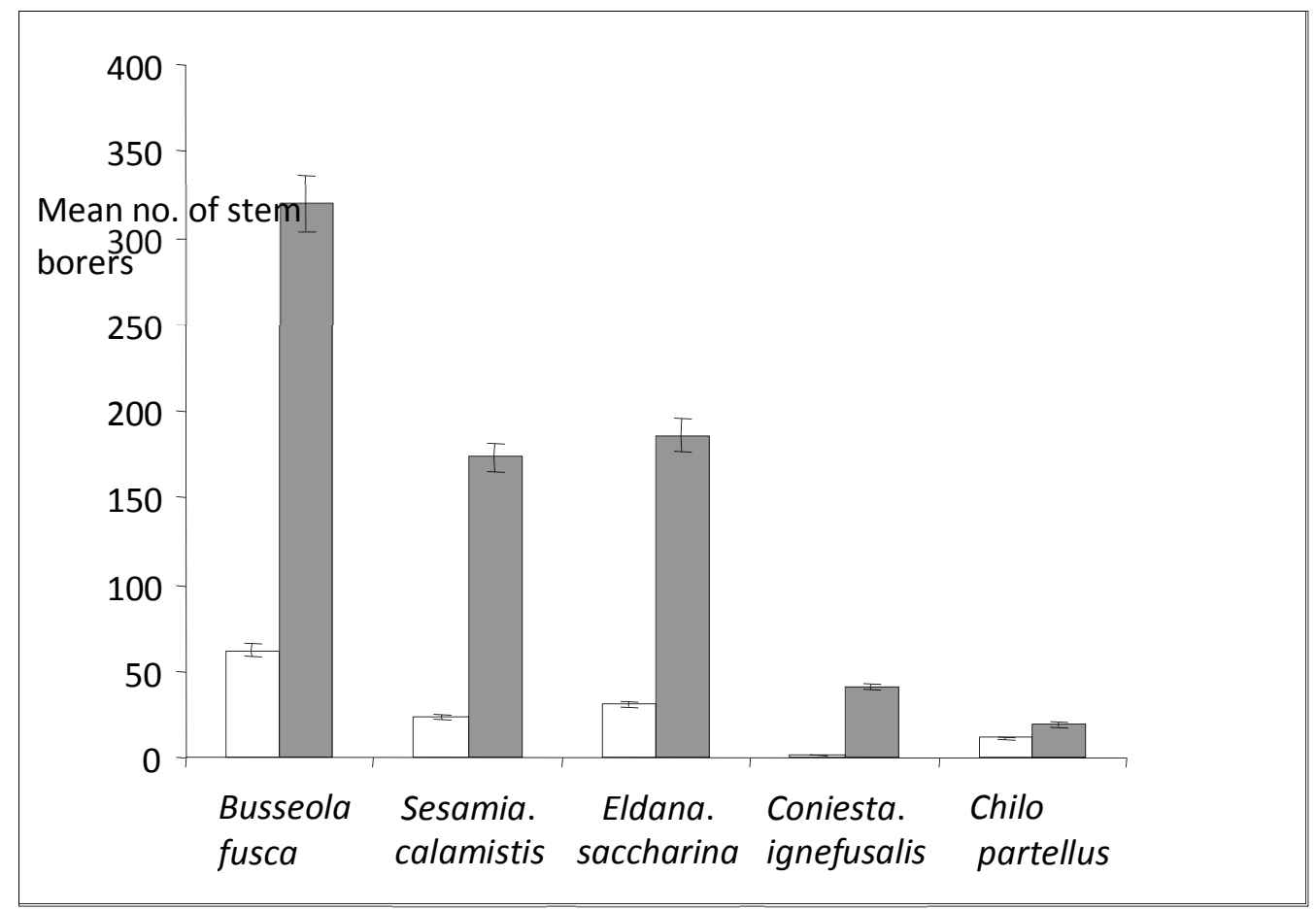

Fig. 2. Composition and relative abundance of maize stem borers $( \pm S E)$ recovered at harvest of the early and late crop

Split application of carbofuran at the rate of $1.5 \mathrm{~kg} / \mathrm{ha}$ significantly $(P<0.05)$ affected stem borer infestation, damage, and yield across planting dates and maize genotypes (Table 1); based on the number of borers in bored stems of treated and untreated plots, percentage control was 63.5 and 86.6 , respectively in the early- and 
late-planted crops. Interaction of carbofuran application with planting date was significant for percentage deadheart, bored stem, bored internode as well as for the number of larva(e)/stem. Similarly, significant interactions were found between carbofuran application and maize genotype for percentage lodged stem and number of borer cavity. 
Table 1. Mean squares from combined analyses of variance (2004 early and late crops) for stem borer infestation, damage and yield of three maize Source of types at Makurdi

\begin{tabular}{|c|c|c|c|c|c|c|c|c|c|}
\hline $\begin{array}{l}\text { Source of } \\
\text { variations }\end{array}$ & $\mathrm{DF}^{*}$ & $\% \mathrm{DH}$ & $\%$ LS & NoLPS & $\% B S$ & $\%$ BIN & NBC & 1000GW & GW \\
\hline Rep & 3 & 0.29 & 0.43 & 0.50 & 494.40 & 43.92 & 0.01 & 1418.30 & 0.11 \\
\hline PD & 1 & $0.01^{\mathrm{NS}}$ & $7.00^{* *}$ & $8.17^{\star *}$ & $675.00^{N S}$ & $2382.20^{\star *}$ & $0.00^{\mathrm{NS}}$ & $248.00^{N S}$ & $8.48^{* *}$ \\
\hline CR & 1 & $24.34^{\star *}$ & $65.75^{\star *} 1$ & $0.27^{\star *}$ & 29008.30 ** & $11618.03^{\star *}$ & $1.28^{\mathrm{NS}}$ & $2.70^{\star \star}$ & $0.35^{\star *}$ \\
\hline MT & 2 & $0.12^{N S}$ & $1.19^{\mathrm{NS}}$ & $0.02^{\mathrm{NS}}$ & $89.60^{\mathrm{NS}}$ & $22.56^{\mathrm{NS}}$ & $0.02^{N S}$ & $53398.80^{N S}$ & $1.49^{* *}$ \\
\hline PDXCR & 1 & $3.91^{* *}$ & $1.44^{\mathrm{NS}}$ & $4.56^{\star \star}$ & $1200.00^{*}$ & $825.93^{* *}$ & $0.03^{N S}$ & $10.20^{N S}$ & $0.02^{N S}$ \\
\hline PDXMT & 2 & $0.08^{\mathrm{NS}}$ & $0.38^{N S}$ & $0.04^{\mathrm{NS}}$ & $18.70^{\mathrm{NS}}$ & $30.62^{N S}$ & $0.01^{N S}$ & $53.60^{N S}$ & $0.18^{*}$ \\
\hline CRXMT & 2 & $0.10^{N S}$ & $1.61^{\star}$ & $0.02^{N S}$ & $452.10^{N S}$ & $52.79^{N S}$ & $0.03^{*}$ & $458.50^{N S}$ & $0.06^{\mathrm{NS}}$ \\
\hline PDXMTXCR & 2 & $0.10^{\mathrm{NS}}$ & $0.15^{\mathrm{NS}}$ & $0.09^{N S}$ & $381.30^{N S}$ & $79.68^{\mathrm{NS}}$ & $0.01^{N S}$ & $17.10^{\mathrm{NS}}$ & $0.07^{N S}$ \\
\hline Error & 33 & 0.20 & 0.39 & 0.10 & 164.10 & 28.93 & 0.01 & 370.80 & 0.04 \\
\hline
\end{tabular}

*DF- degree of freedom; DH- dead heart; LS- lodged stem; NoLPS- no of larva(e) per stem; BS- bored stem; BIN- bored internode; NBC- number of borer cavity; GW- grain weight; PD- planting date; CR- carbofuran; MT- maize type. 
Maize type did not influence the degree of borer damage; however, yield trend showed flint $(1.42 \mathrm{t} / \mathrm{ha})<$ pop $(1.09$ $\mathrm{t} / \mathrm{ha})<$ sweet $(1.09 \mathrm{t} / \mathrm{ha})$ in the treated plots. Comparable figures for the untreated plots were flint $(1.15 \mathrm{t} / \mathrm{ha})<$ pop maize $(0.86 \mathrm{t} / \mathrm{ha})<$ sweet maize $(0.64 \mathrm{t} / \mathrm{ha})$. Across genotypes, the early-planted crop significantly $(P<0.05)$ yielded higher (1.5 t/ha in treated and $1.24 \mathrm{t} / \mathrm{ha}$ in untreated plots) than the late-planted (0.62 $\mathrm{t} / \mathrm{ha}$ in the treated and $0.48 \mathrm{t} / \mathrm{ha}$ in the untreated plots) crop. Yield loss due to borer damage to the early crop was $14.0 \%$; that for the late crop was 1.5-fold higher.

Each of the stem borer damage parameters was negatively correlated with yield (Table 2) but no parameter had coefficient of determination high enough to preponderantly account for the variation in grain yield. Of the four parameters evaluated, proportions of lodged stems and bored internodes consistently had higher negative coefficients than others. Irrespective of the planting date, positive and highly significant correlations were found between (a) percentage lodged stems and each of bored stems and bored internodes; (b) percentage of bored internodes and each of bored stems and dead-hearts; and (c) percentage bored stem and dead-hearts.

Table 2: Coefficients of the correlation of borer damage parameters with each other and with yield in the early and late planting 2004

\begin{tabular}{|c|c|c|c|c|c|}
\hline Parameters & Yield & LS & BIN & BS & $\mathrm{DH}$ \\
\hline \multicolumn{6}{|c|}{ Early Crop } \\
\hline Yield & 1.000 & & & & \\
\hline LS & -0.260 & 1.000 & & & \\
\hline BIN & -0.259 & $0.821^{* *}$ & 1.000 & & \\
\hline BS & -0.138 & $0.751^{\star *}$ & $0.947^{\star \star}$ & 1.000 & \\
\hline $\mathrm{DH}$ & -0.222 & $0.799^{* *}$ & $0.5781^{* *}$ & $0.760^{\star *}$ & 1.000 \\
\hline \multicolumn{6}{|c|}{ Late Crop } \\
\hline Yield & 1.000 & & & & \\
\hline LS & -0.414 & 1.000 & & & \\
\hline BIN & -0.288 & $0.831^{* *}$ & 1.000 & & \\
\hline BS & -0.255 & $0.743^{* *}$ & $0.875^{\star *}$ & 1.000 & \\
\hline $\mathrm{DH}$ & -0.036 & 0.383 & $0.535^{\star *}$ & $0.535^{\star \star}$ & 1.000 \\
\hline
\end{tabular}

*LS=lodged stem; BIN = Bored internodes; BS= number of Bored stems; $\mathrm{DH}=$ Number of Dead hearts

\subsection{DISCUSSION}

Severity of stem borer infestation and damage have been shown to vary with borer species, borer generation, infestation level, plant growth stage, varietal resistance, season, agro-ecology, and weather (Bosque-Perez, 1995; Ajayi and Labe, 1990; Polaszek, 1998). Though recommendations on dates appropriate for sowing exist across all agro-ecological zones where maize is cultivated, staggered dates of sowing is prevalent in Nigeria thereby making available to borers maize stands at different phenological stages for completion of several generations (1-4).

Consistent with the findings of Ogunwolu (1987), and Okweche and Umoetok (2012), B. fusca was the most abundant species at Makurdi; elsewhere, for example Amakama, Uyo, and Ife, S. calamistis or $E$. saccharina predominated (Bosque-Perez and Mareck, 1991; Ogunwolu, 1987; Sosan and Daramola, 1999). As previously observed by Bosque-Perez and Dabrowski (1989), as well as Polaszek (1998), the early- planted crop was less severely infested and damaged compared with the later crop.

Up to $80 \%$ yield loss has been attributed to stem borer damage in Africa \{van den Berg, 2009) and 20-40 $\%$ loss in Nigeria (IITA, 2013). The significant reductions in infestation and damage accompanied by yield increases with application of carbofuran against stem borers agreed with the findings of Egwuatu and Ita (1982), Daramola (1985), Halimie et al. (1989), and Khan and Amjad (2000). Daramola (1985) alluded to the contributory role of nematicidal action of carbofuran in increasing yield in his study.

According to Ajala (1994), stem tunneling was the major cause of yield loss in maize attacked by stem borers; but data from a subsequent experiment failed to substantiate this as its correlation with yield loss $(r=-0.2$, $P>0.05)$ was low and not significant. Sosan and Daramola (1999) found that yield loss could be consistently and reliably predicted from percentage bored node and internode. In that study, the respective ranges of data reported were $11.18-34.18 \%$ and $7.92-18.92 \%$. This was not our experience. Though the ranges of bored 
internodes in our study were wider, $7.07-29.9 \%$ for the early crop and $12.9-52.3 \%$ for the late crop, correlations with yield were low

(see Table 2) and not significant $(P>0.05)$. Explanation may be found in differences in borer species composition and abundance and in differences in environmental conditions mediating crop-pest interaction.

As observed in the study by Ajala et al. (2010), and Daramola (1985), significantly positive correlations were detected between borer foliar and stem damage. However, the advantage of reduced sampling time and cost with foliar sampling is nullified by its low efficiency as a predictor of yield loss. In the absence of a robust yield loss predictive model based on borer damage detection in early crop growth stages at Makurdi, use of carbofuran will continue to be prophylactic.

\section{REFERENCES}

Ajala, S.O. 1994. Maize (Zea mays L.) stem borer (Chilo partellus Swinhoe) infestation/damage and plant resistance. Maydica 39:203-206.

Ajala, S. O. and Saxena, K. N. 1994. Interrelationship among Chilo partellus damage parameters and their contribution to grain yield reduction in maize (Zea mays L.). Appl. Entomol. Zool. 29 (4): 469476.

Ajala, S. O., Nour, A. M., Ampong-Nyarko, K. and Odindo, M. O. 2010. Evaluation of maize (Zea mays L.) genotypes as a component of integrated stem borer (Chilo partellus Swinhoe) management in coastal region of Kenya. Afri J. Agric. Res. 5(8): 758-763.

Anon. 2012. Maize supply to local industries in Nigeria: the feasibility report. http://www.foramfera.com/index.php/investmentopportunities-in-nigeira/item/146-supplying-maize-to-localindustries-in-nigeria-how-viable?

Badmus, M. A. and Ariyo, O. S. 2011. Forecasting cultivated areas and production of maize in Nigeria using ARIMA Model. Asian J. Agric. Sci. 3 (3): 171-176.

Balogun, O. S \& Tanimola, O. S. 2001. Preliminary studies on the occurrence of stem borer and incidence of stalk rot under varying plant population densities in maize. J. Agric. Res. \& Dev. 1: 67-73.

Bosque-Perez, N. A. 1995. Major insect pests of maize in Africa:biology and control.IITA Research Guide 30, 60 pp.

Bosque-Perez, N. A. \& Dabrowski, Z.T. 1989. Mass rearing of the maize stem borer S. calamistis and E. saccharina at IITA. In: Towards insect resistant maize for the third world. Proceedings of the International Symposium on Methodologies for Developing Resistance to Maize Insects. CIMMYT, Mexico City. Pp 22-26.

Bosque-Perez, N. A. \& Mareck, J. H. 1991. Distribution and species composition of lepdopterous maize borers in southern Nigeria. IITA Research No. 3: 9-14.

Daramola, A. M. 1985. Comparative effectiveness of carbofuran and carbaryl in the control of maize stem borer. Nig. J. Plt. Prot., 9, 54:59.
Effa, E. B., Uwah, D. F., Iwo, G. A., Obok, E. E. and Ukoha, G. O. 2012 Yield performance of popcorn (Zea mays L. everta) under lime and nitrogen fertilization on an acid soil. J. Agric. Sci. 4 (10): 12- 19.

Egwuatu, R. I. and Ita, C. B. 1982. Some effects of single and split application of carbofuran on the incidence of and damage by Locris maculata, Busseola $\quad$ fusca and Sesamia calamistis on maize. Trop. Pest Manage. 28: 277-283.

Farid, A., Khan, M. I. N.,Khan, A., Khattak, S. U. K., Sattar, A. and Sattar, A. 2007. Studies on maize stem borer, Chilo partellus in Peshawar Valley. Pak.J. Zool. 39 (2): 127-131.

Halimie, M. Mughal, A. and Rana, Z. A. 1989. Response of different times of carbofuran (Furadan $3 \mathrm{G}$ ) application on maize stem borer incidence and yield of the corp. J. Agric. Res. 27: 337-340.

IITA 2013. Maize. IITA Research to Nourish Africa. http://www.iita.org/maize.

Kekule, T.O., Latigo, M.W. \& Okoth, V.A.O. (1997). Distribution and damage by Chilo partellus (Swinhoe), Busseola fusca (Fuller), Eldana saccharina (Waller) and Sesamia calamistis (Hampson) in two locations in Uganda. Afr. Crop Sci, J. 5(4), 345-393.

Khan, S. M. and Amjad, M. 2000. Chemical control of maize stem borer (Chilo partellus Swin.). Pak. J. Biol. Sci, 3 (12): 2116-2118.

Leyenaar, P. and Hunter, R. B. 1977. Effect of stem borer damage on maize yield in the coastal savanna zone of Ghana. Ghana J. Agric. Sci. 10: 67-70.

Ogunwolu, E.O. 1987. Efficay of carbofuran against lepidopterous stem borers of maize. Nig. J. Agron., 2(2), 27-32.

Okweche, S. I. and Umoetok, S. B. A. 2012. The distribution of maize stem borers in Cross River State, Nigeria. Intl. J. PI. Anim. \& Env. Sci. 2(1): 82-86.

Okweche, S.I., Ukeh, D.A. and Ogunwolu, E.O. 2010. Field infestation of three maize (Zea mays L.) genotypes by lepidopteran stem borers in Makurdi, Nigeria. Global J. Agric. Sci., 9 (1), 41-45.

Polaszek, A. 1998. Africa Cercal Stem Borers: Economic Importance. Taxonomy, Natural Enemies and control. Wallingford: $C A B$ International. $530 \mathrm{pp}$.

Sharma, P. N. and Gautam, P. 2010. Assessment of yield loss in maize due to attack by the maize borer, Chilo partellus (Swinhoe). Nepal J. Sci. \& Technol. 11: 25-30.

Sosan, M. B. and Daramola, A. M. 1999. Studies on the relationship between methods of assessing lepidopterous stem-borer infestation and grain yield losses in maize, Zea mays L. Niger. J. PI. Prot. 18:12-20.

Tena, W. and Beyene, S. 2011. Identification of growth limiting nutrients in Alfisols: Soil Physico-chemical properties, nutrient concentrations and Biomass yield of maize. Am. J. Plt. Nutri. Fert. Technol., 1, 23-35.

Ukeh, D.A., Emosairue, S.O., Udo, I.A. and Ofem, U.A. 2007. Field evaluation of neem (Azadirachta indica A. Juss) products for the management of lepidopterous stem borers of maize (Zea mays L.) in Calabar, Nigeria. Res. J. Appl. Sc., 2(6), 653-658.

Undie, U.L., Uwah, D.F. and Attoe, E.F. 2012. Growth and development of late season maize/soybean intercropping in response to Nitrogen and crop arrangement in the forest Agro-ecology of south southern Nigeria. Int. J. Agric. Res., 7(1), 1-16.

van den Berg, J. 2009. Case study: Vetiver grass as component of integrated management systems. http://www.vetiver.org/ETH_WORKSHOP _09/ETH_A3a.pdf. 